\title{
Influence of Sediment Remediation on Protection Aims and Landscape Characteristics of Special Nature Reserve Carska Bara
}

\author{
Stojanović Vladimir ${ }^{A *}$, Pantelić MilanaA, Savić Stevan, Dolinaj Dragan ${ }^{A}$, Leščešen Igor $^{B}$ \\ Received: September 2012 | Revised: December 2012 | Accepted: December 2012
}

\begin{abstract}
The focus of this research is Special nature reserve Carska bara that is situated in the area of central Banat (Vojvodina, Serbia). The whole territory of the Reserve and the surrounding area represents space that has been under the influence of human activities since the very beginning of the development of human communities. Another great influence comes from the process of melioration of the whole area and mainly of the river Begej, which consequently results in changes in sediments and their quality. Sediment has a strong influence on numerous goals and functions of protection. It changes the characteristics of the landscape and ecosystems. That is why the process of sediment remediation, through the process of demudding, is of crucial importance for the protection of this area and its natural values. Remediation influences some important aims of managing the area such as nature protection, education and tourism.
\end{abstract}

Key words: sediments, remediation, Carska bara, nature protection, protected area.

\section{Introduction}

Sediment is an essential and dynamic component of all aquatic systems that, due to its tendency of binding, represents a reservoir of toxic substances of anthropogenic origin. Sediment reaches waterways influenced by many different factors such as: drainage of geological base and soil, layering of particles of eolian sediments or decaying of aquatic and inshore vegetation. With the problem of uncleaned waste waters reaching river courses, the problem becomes even more serious because that process causes a decrease in decomposed oxygen, eutrophication, appearance of toxic substances and composition of mud, i.e. sediments. That is why the sediment quality is an important component in the programmes of protection of waters and whole environmental system (Dalmacija at al., 2008). A problem becomes big- ger if the area is defined as the protected one and as such is subject to the standards of the Law on nature protection.

Special nature reserve Carska bara is situated in the area of central Banat, in wide alluvial river plain and on the place where waters from the Tisa and Begej flooded before the built of the system of embankments. This whole area has been, during the course of history and development of human communities, under the influence of a number of social and economic activities, which influenced the creation of the final landscape character (Stojanović, Pavić, Ristanović, 2009). It can generally be defined as a cultural area with well-preserved fragments of true nature (Pil et al., 2010). This also refers to surface hydrohraphy that belongs to the group of basic values in the reserve and that, during the $20^{\text {th }}$ century

A Climatology and Hydrology Research Centre, Faculty of Science, University of Novi Sad, Trg Dositeja Obradovića 3, 21000 Novi Sad, Serbia

B Department of Geography, Tourism and Hotel Management, Faculty of Science, University of Novi Sad, Trg Dositeja Obradovića 3, 21000 Novi Sad, Serbia

* Corresponding author: Vladimir Stojanović, e-mail: vladimir.stojanovic@dgt.uns.ac.rs 
(Ham, 1975), and even before, was under the strong influence of melioration and water management. In those kinds of circumstances, the protection of these isolated fragments represents a challenge in the field of nature protection and especially if we take into consideration the process of sedimentation and pollution of sediments that seriously endanger both the surface hydrography and the whole concept of the preservation of this reserve.

The basic goals of this research are directed towards emphasising the importance of changes in the landscape characteristics caused by sedimentation for the realisation of goals and functions of nature protection in the nature reserve Carska bara. Moreover, this paper emphasises how the regulation of hydrologic objects can influence the process of sedimentation of this kind of protected areas.

\section{Landscape history and changes in the area in and around Special nature reserve Carska bara}

History of the landscape around the special nature reserve has a complex chronology and each of the periods of development of human communities has reflected on the evolution of the natural features of the entire region in a specific way. Three important economic activities, some of which date from the early period of human communities, have visibly influenced the formation of the landscape of Carska bara and its environment (agriculture, including animal husbandry, as well as fishing and water management).

The first impacts on landscape features date back to the prehistoric period. Agriculture has been one of the most important human activities in this region for millennia. It is, also, closely connected with the first inhabitants of this part of the Pannonian Plain. Archeological sites - Krstićeva humka and Batka near Perlez, which incidentally contain residues of Starčevo and Körös cultures, testify on the impact of agriculture onto this area. The early Neolithic period brought about significant change in the behavior of human communities. Survival strategy based on hunting and gathering was gradually replaced by food production through agricultural development. The original use of the resources of the land was accompanied by an equal development of farming. In this early period relatively small amounts of grain, such as einkorn wheat, barley, rye, lentils and millet, were produced. Domestic animals that were bred were cattle, sheep, goats and pigs (Medović, 2001). Here, we can see the fact that agricultural activity, with associated plant and animal species, has been an integral part of the ecosystem for millennia.
People began to deal with fish farming and the development of fishing in this area, back in 1762, two years after the work on Belo jezero Lake had been finished. Belo jezero Lake is, even today, a part of the nearby fishpond. From that moment until the present day the whole area has been ameliorated and regulated, so that a total of 16 lakes were formed. A century later, the magazine "Torontal" announced that a lake is to be modified into a fishpond on the estate of Count Felix Harnoncourt. That lake is the present Belo jezero Lake. According to the 1894 data, fish was caught in an organised manner from an area of water covering a total of 780 ha. Four years later, the construction of Belo jezero Lake was completed, along with the regulation of supply and discharge of a certain amount of water. The fishpond had developed gradually, and in the period up to World War I, it included four northern lakes, four southern lakes and lakes Turka, Bart and Šovajka (Marošan et al., 1992). The construction of the fishpond created artificial habitats which certain species inhabited, primarily birds that lost their natural habitats due to amelioration.

Strong influences on both the core physiognomy of the area and the geoecological characteristics of this part of Banat began in the 19th century, and resulted in changes in the morphology of the terrain and in the water regime (Figure 1). The building of embankments, as forms of anthropogenic relief, prevented flood waves from the Begej and the Tisa to reach important ecosystems. This process had continued into the $20^{\text {th }}$ century, when the whole area became surrounded by embankments. Complete isolation was achieved in 1974, because the part of the new embankment near the village of Perlez, was completed. The final years this area was flooded were 1972 and 1973. Before the construction of the embankments, this whole area would be flooded by high waters of the Tisa and the Begej. This happened when the water level exceeded $340 \mathrm{~cm}$. The barrage and lock at the confluence of the Begej and the Tisa would then be shut down, and the whole area would be flooded. The flood wave travelled from the confluence, reached the Perleska bara Pond, and continued to spread northward to the former barrage and lock in Ečka. Only higher locations would remain dry, two of which were the banks of the Begej and beams in the Perleska bara Pond. At the time of higher water levels $(550 \mathrm{~cm})$, the coast of the Begej was flooded and then the whole area looked like a lake dappled with willow trees (Ham, 1975). Embankments primarily led to the fragmentation of local habitats. Large areas of forest and steppe vegetation were destroyed, which opened the possibility of creating a cultural landscape in which there are islands of genuine nature. 


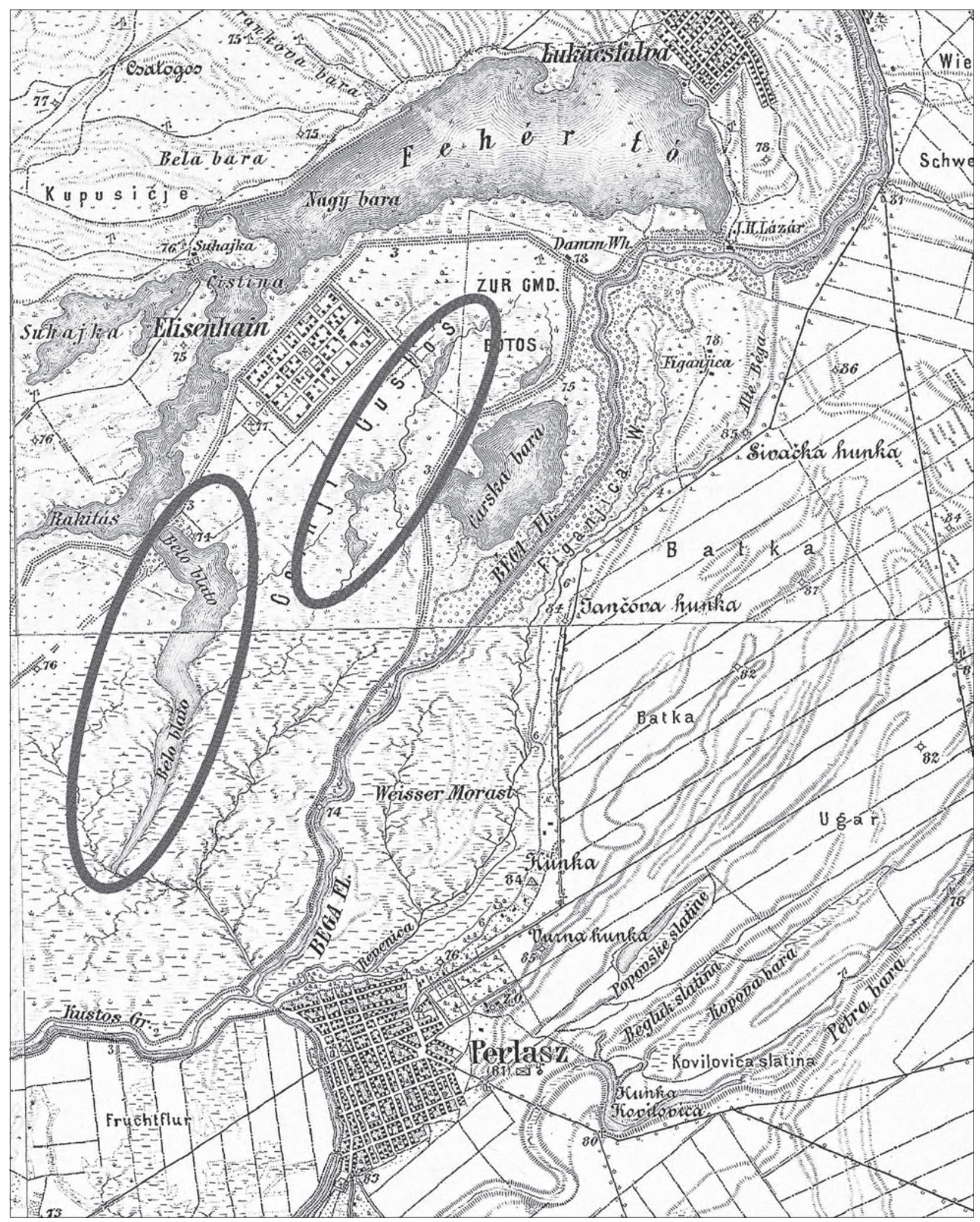

Figure 1. Map from the early $20^{\text {th }}$ century indicates the significant changes that have occurred in the area of Carska bara protected area

The process of construction of embankments significantly changed the geoecological conditions of the environment in the surface hydrography. The active bed of the Begej was cut off on several locations by dams and running water was transformed into stag- nant water. This led to a change in the regime of formation of sediments, as well as their chemical composition, which were further disrupted by the discharge of waste water from the nearby fishpond (Nježić, Rosić, 2008). 


\section{Sedimentation and sediment quality as geoecological and chemical condition of the environment in the reserve Carska bara}

Important and crucial changes in the ecosystems happened when the new river bed of the Begej was dug. The works began in the mid 1960s as part of the realisation of the Hydrosystem Danube-Tisa-Danube. The Begej channel (navigable Begej) opened for navigation in 1971 when the present bed was baffled at the place where today's hotel Sibil is located all the way to the lock at the Tisa River estuary. This process significantly changed the water regime of the river. Especially negative consequences were caused by filling the $\mathrm{Ti}$ ganjica and Perleska bara Pond with dug soil which caused water shallowing and depression diminishing. In just a few years time, the whole complexes became overgrown with willows and macrophyte. Stari Begej was baffled also a nit southern at Perlez, which connected the old and new embankment (Ham, 1975). Such changes in surface hydrography of the Nature reserve significantly influenced underground waters which then changed not only the entire hydrological characteristics of the whole area but its biogeographical characteristics as well.

Abandoned river bed, cut off meanders and numerous river arms got isolated from the network of water course and as such became independent hydrological objects. Before the Begej was regulated, water regularly flooded this vast swamp area. After water withdrawal, higher parts of swamp area remained dry and represented a border between active streams on one side and fluvial lakes and marshes on the other. Apart from water, river filled these depressions with river sediments as well. However, during years with more precipitation when the river is richer in water and the transport force of water in the river bed is stronger than usually, lakes and swamps were cleaned from sediments and their basins partially deepened. These cyclical activities of the Begej River stopped after numerous melioration works which changed the entire physiognomy of the river bed (Figure 2). From the hydrological aspect this space was regulated and the changes influenced the river water regime. Cyclical flooding stopped after regulation works. Sediments in depressions remained tied to lake and swamp basins while the natural demudding also stopped (Figure 3). Growth of sediments on the bottom of river arms and swamps is constant while the lack of water and large organic production in stagnant water make this organic component have significant share in total sediment balance. This type of tendency represents a problem for any kind of hydrological object while mudding, smaller amount of oxygen in water and decrease in water reflection are just some of the problems that are already present on the area of the Special nature reserve Carska bara.
At the same time it is necessary to pay attention to the influence of climatic changes on protected areas, i.e. the whole environment that have been in the focus of scientific researches in the last two decades (Mortsch, 1998; Walther et al., 2002; Dawson et al., 2003; IPCC, 2007; Erwin, 2009). Climate changes probably have indirect influence on overall sediment balance of Crska bara as hydrological object. Depth of water profile, mugging process, sedimentation of plant residue and water reflection surface depend mostly on surrounding surface waters and underground waters. However, additional negative contributions can come from certain meteorological parameters (precipitation, air temperature, evaporation). During the period between 1949 and 2000 in the area of Zrenjanin (Republic Hidrometeorological Service of Serbia, 1949-2010) precipitation has a slight tendency of growth accompanied with unfavourable annual distribution, which in Vojvodina, being the region with relatively small amount of precipitation (about $600 \mathrm{~mm}$ ), can have even even greater negative character (Spasov, 2003). Such a situation causes larger number of dry periods, especially during summer and spring, and has indirect influence on the levels of underground and surface waters. In the same mentioned period, temperatures show significant growing tendencies, especially during summer, spring and winter. Such trends negatively influence water thermics which later contribute to a more intensive euthrofication and similar negative processes directly connected to sedimentation balance of the reserve Carska bara. At the same time, despite relatively higher amount of precipitation, loss of water happens because of the process of evaporation. That is how certain climatic processes that would usually be described as positive ones (in the sense of the sustainability of wetlands) are neutralised by other negative climatic changes. Based on the above mentioned, despite the fact that climatic changes represent an indirect factor, a detailed monitoring of the most important meteorological parameters is necessary if we want thoroughly to monitor all the factors that influence the process of sedimentation in the reserve.

One of the important goals in the process of sediment studying is collecting information on the presence of priority substances in the sediment of the Special nature reserve Carska bara in order to perform risk assessment if the changes in the ecological condition and decrease in ecological potential due to poor chemical status of the sediment are proved to exist.

Sediment is the habitat for numerous organisms, important source of nutrients for organism and certain species in food chain while the sediment dynamics (erosion, sedimentation and other) make favourable conditions for biodiversity. Since it shows severely expressed tendency to bind, it is considered that the 


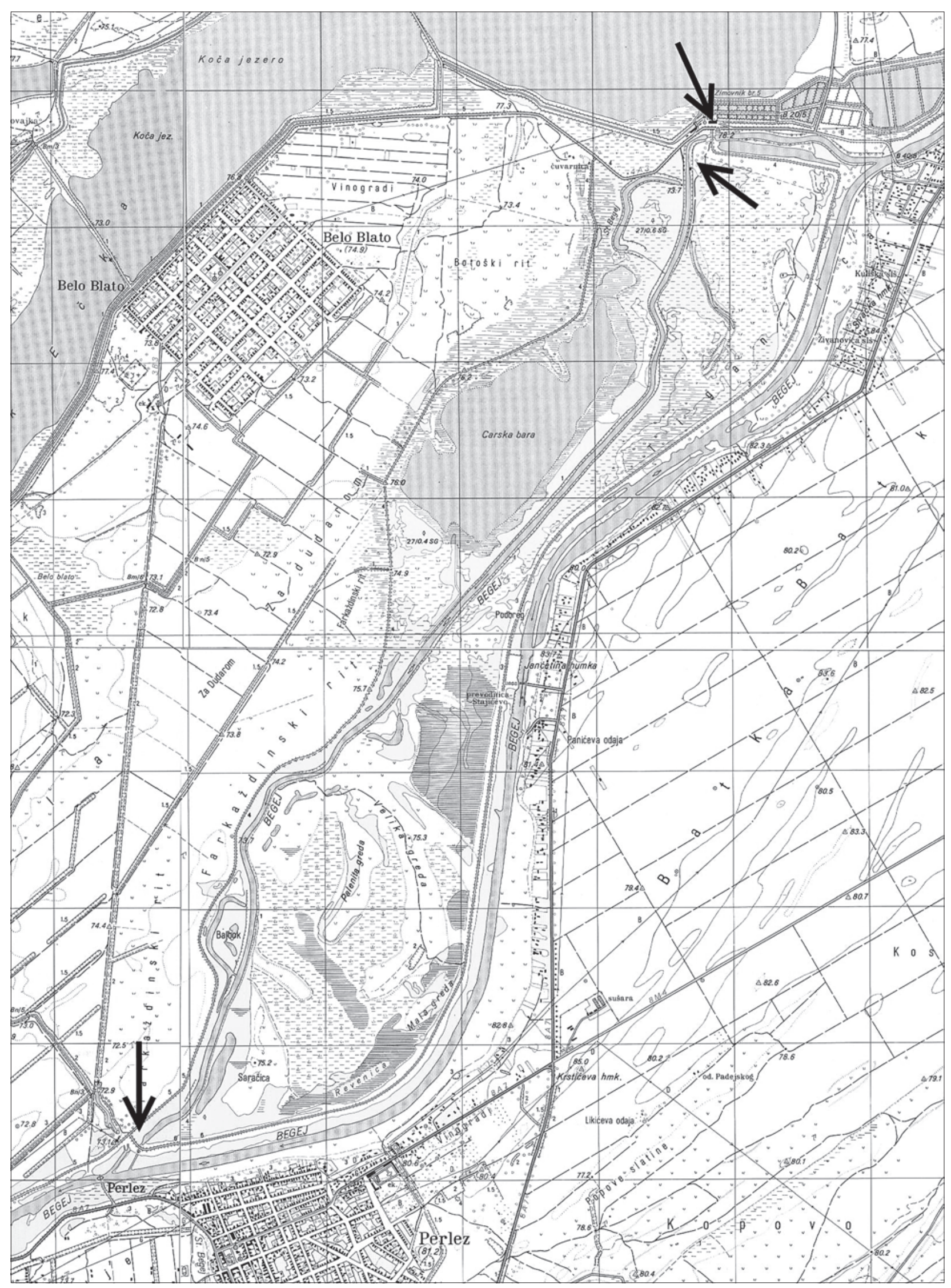

Figure 2. Key geological and hydrological factor of sedimentation for certain hydrological objects is baffling of the river bed in the $20^{\text {th }}$ century 


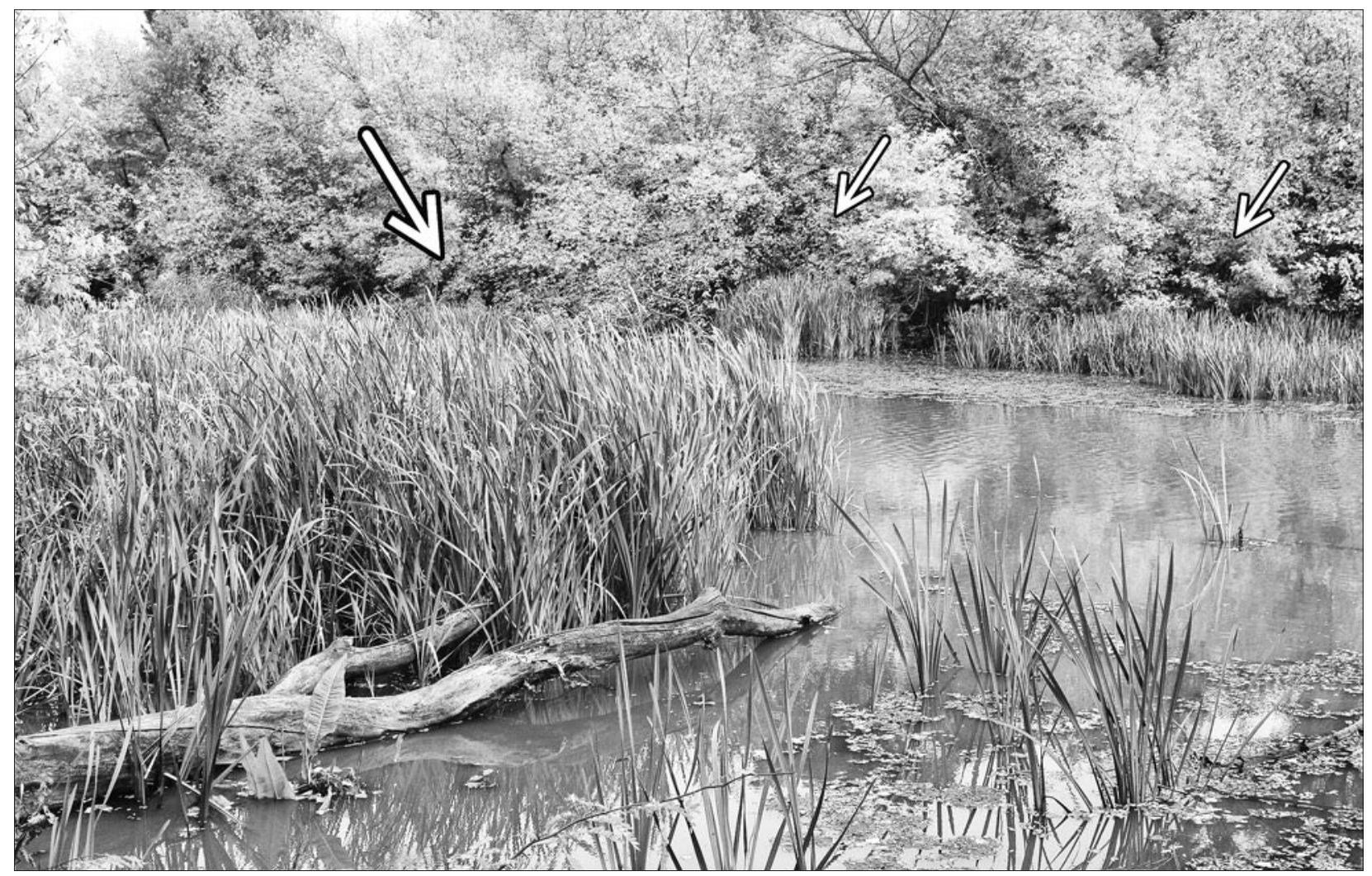

Figure 3. Sedimentation visible on cut-off river arms of the Begej (Stari Begej) where extensive flourishing of the vegetation happens along the banks; Photo: V. Stojanović

reservoir of toxic and persistent compounds is of dominant anthropogenic origin. Polluted sediments have direct negative influence on the fauna of the bottom and represent long-term sources of toxic pollutants influencing negatively living world and humans through food chain, water of direct contact. When the process of revitalisation is in progress it is necessary to perform disposal of polluted sediments, remediation, without negative influences on the environment. Data on the chemical characteristics of the sediments represent the base for selecting remediation techniques and later monitoring of sediment quality during the process of remediation and until final disposition that will not have negative consequences on the environment (Dalmacija et al., 2008).

Researches were performed on two profiles (entrance into Carska bara and at the pier at the bank of the river arm Stari Begej). Since Serbia does not have suitable regulations for estimating sediment quality, recommendations given by ICPDR (International Commission for the Protection of the Danube River) were used for the interpretation of the results.

When general physical and chemical indicator of sediment quality are concerned, nutrients do not show high concentrations that would derogate from limit values of mud that are for example used in Denmark in agriculture and whose average concentrations are $40 \mathrm{~g} / \mathrm{kg}$ of dry material for nitrogen and $25 \mathrm{~g} / \mathrm{kg}$ of dry material for phosphorus. These concentrations should not have any kind of negative consequences upon environment in case of deposition but do represent a problem from the aspect of possible emitting of nutrients from sediments which would cause favourable conditions for the appearance for eutrophication. Results for the contents of HPK and $\mathrm{BPK}_{5}$ show high values for $\mathrm{HPK} / \mathrm{BPK}$ correlation which indicates the presence of organic pollution that is not biologically degradable. Generally, it is noticeable that the contents of organic substances are higher in surface than in deeper layers of the sediment. When we take into consideration high level of organic substances and compare them with the conditions in standard sediment, sediment in Carska bara is classified as slightly polluted (class 2) (Dalmacija et al., 2008).

When the content of heavy metals and arsenic are considered, few elements from this group exceed permitted limits.

Sediment quality when the presence of lead is in question is rather adequate. However, there is a certain influence of diffuse sources of pollution such as traffic. The permitted level of mercury is exceeded due to industrial waste waters (especially from the unit for chlorine production), usage of mercury pesticides for seed protection or usage of mercury compounds in lighters of explosive units. Copper is present in such high concentrations that cause possible negative ef- 
fects. Copper in sediment is probably the result of waste waters that come either from metal industry or pig husbandry. Significant values of chromium are also present in the sediment. Chromium also comes from industrial waste waters and has a potential negative effect. A very high concentration of zinc is present on the profile at the pier. Zinc has the same origin as copper and chromium (Dalmacija et al., 2010).

Presence of arsenic in the sediment has a negative ecotoxic effect because its values significantly exceed values determined by ICPDR. The most probable source of arsenic is drinking water that contains arsenic (drinking water that is provided for the town of Zrenjanin in the neighbourhood of Carska bara).

About 50 compounds were identified in the sediment of Carska bara. The greatest number of them are aliphatic hydrocarbon and polycyclic aromatic hydrocarbon, as well as benzene derivates which, due to their hydrophobe have a tendency to accumulate in the sediments. Among identified compounds there are compounds of natural origin that can be industrially applied and compounds that are of synthetic origin and as such represent markers of anthropogenic activities.

When the group of pesticides is in question, dyphenil-ether was detected in sediments. Potential for accumulation in sediments was shown also by those compounds that are used in agents for personal hygiene and cosmetic products such as 1-hexadecanole and 1-ethyl-2-hexanol, components in sun protection creams - benyophenone and menthol and camphor (component of perfumes) (Dalmacija et al., 2010).

\section{Interdependence of sedimentation, sediment remediation and nature protection}

Special nature reserve Carska bara has a complex chronology of protection. The first decision on the protection of the area was made in 1955, when the site "Vojtina mlaka" was protected due to its outstanding natural beauty on the basis of the, then relevant, Law on the Protection of Cultural Monuments and Natural Rarities. The next act of protection came in 1986, when the municipality of Zrenjanin decided to declare Stari Begej a national park and Carska bara a strict nature reserve (Budakov et al., 1993). A regulation of the Government of the Republic of Serbia, at the initiative of the Institute for Nature Conservation of Serbia adopted the Regulation on the Protection of the Special nature reserve "Carska bara-Stari Begej" in 1994 (Official Gazette of the Republic of Serbia, 56/1994). A new Regulation on the Protection of the reserve, now named Carska bara, was adopted in 2011, which partially changed the regimes of protec- tion and increased the total area of protected areas to 4726 ha (Official Gazette of the Republic of Serbia, 46/2011). Like many other protected areas, Special nature reserve Carska bara is threatened by certain factors. The most prominent among them is the change in the water regime and regulation of surface waters, which led to the mudding of certain localities, mostly in the northern part of the cut-off branch of Stari Begej. How can management of protection of nature affect the prevention of such tendencies?

The link between sediment, sediment remediation and protection of nature can be seen in the legal framework of protection. According to the Law on the Protection of Nature, in Serbia, a special nature reserve is defined as an area of unmodified or slightly modified nature of particular importance because of its uniqueness, rarity or representativeness, intended for the preservation of existing natural features, gene fund, ecological balance, monitoring of natural phenomena and processes, scientific research and education, controlled visits and the preservation of traditional ways of life (Official Gazette of the Republic of Serbia, 36/2009). It is a protected area that corresponds with category 4 by IUCN categorization - An area of management of habitats or species, where the goal of management is protection through intervention or active measures to create the conditions for the survival of certain species (IUCN Protected Area Management Categories, www.iucn.org). The relevant Law on Nature Protection and the Declaration of Special nature reserve Carska bara, enable activities of revitalization of the channels and maintaining their fluency at the second level of protection, as well as demudding of natural waterways and maintaining the channels at the third level of protection. This allows for the possibility of preserving native ecosystems through human intervention.

Contemporary laws and regulations regarding nature protection enabled demudding as one of the techniques of sediment remediation as it was proved that sediments in certain parts of the reserve represent dangerous threat to natural values. Such kind of intervention seems to be necessary. Aimed at protecting the protected area, the managing body of Special nature reserve Carska bara initiated cleaning of part of the river bed (Suggestion of technical solution for removal of mud from part of the water course Stari Begej in Special nature reserve "Stari Begej - Carska bara", 2003). Project was realised in 2008 when demudding process was performed in a length of about $800 \mathrm{~m}$. Settling basin on the contact between Belo Jezero Lake (that is part of the fishpond Ečka) and Stari Begej was built a year later. This settling basin is intended to be used for sedimentation of organic substances in water that is released from the fishpond during fish catch which would cause in- 
Table 1. Effect of the pollution or scope of sediments and remediation based on the function and aims of nature protection in Special nature reserve Carska bara

\begin{tabular}{|l|l|l|l|l|l|}
\hline \multicolumn{2}{|l|}{ Ecological } & \multicolumn{2}{l|}{ Socio-cultural } & \multicolumn{2}{l|}{ Economic } \\
\hline $\begin{array}{l}\text { Protection of plants and animals } \\
\text { biodiversity) }\end{array}$ & +++ & $\begin{array}{l}\text { Protection of social integrity of } \\
\text { local population }\end{array}$ & - & Tourism and recreation & +++ \\
\hline Protection of habitats & +++ & Protection of cultural heritage & - & Fishery & + \\
\hline $\begin{array}{l}\text { Protection of original relief } \\
\text { characteristics }\end{array}$ & +++ & $\begin{array}{l}\text { Education of local population and } \\
\text { visitors }\end{array}$ & ++ & Reed processing & + \\
\hline
\end{tabular}

Interpretation: - not present; + low; ++ medium; +++ high

flow of water without presence of mud into the reserve (Pil et al., 2010). If we consider the fact that the valorisation of protected areas, their goals and function are divided into three groups - ecological, socio-cultural and economic (Prato, Fagre, 2005) and if we adjust that to the characteristics of the Special nature reserve Carska bara, then we can present contemporary and potential effect of polluted sediments as it was done in table 1.

Numerous mentioned effects cause a change in the quality of water and sediments in this area (melioration, agriculture, and fishery) which influences the morphology of the terrain and landscape characteristics, i.e. ecological values and ecological objectives of managing the reserve. Moreover, growth and dying of algae and plants in the bed of Stari Begej causes mudding. This process is rather progressive while the height of mud in some parts of the river bed reaches three metres. This phenomenon generally endangers this water ecosystem and causes decrease in water reflection. Macrophyte vegetation overgrows this water surface and transforms it into a swamp. This whole process endangers biodiversity because certain species disappear. Demudding as a process, which started with the realisation of the project from 2008 , enables better circulation of water which consequently influences the quality of sediment. This process positively influences the entire biodiversity and helps the process of nature protection, which makes natural values less endangered.

One of the dominant social functions and values of this protected area is education. The reserve is a wellknown destination for the purposes of excursion tourism on the national level. One of the reasons for that are authentic characteristics of this wetland, whose values have been confirmed and included on the list of Ramsar sites in 1996. Due to its preserved natural values students of geography, biology, ecology and tourism choose this destination for their practical training. If this values experience mudding and pollution this area will become less popular for the purposes of education. That kind of tendency shall certainly not suit global trends in the area of sustainable development.

Tourism is a dominant economic activity in the reserve. The development of tourism can be seen mainly through the realisation of excursion tourism and ec- otourism. The main tourist offer is voyage in a tourist ship along Stari Begej. This tourist activity is in direct correlation with condition and thickness of sediment in the bed of Stari Begej. If we take into consideration the thickness of sediment of three metres, it is obvious that this segment of tourist offer is endangered with the process sedimentation. Moreover, ecotourism as the form of tourism requires area of rich biodiversity and any further decrease in the number of plant and animal species would endanger the idea of the development of this form of tourism. Expectations are high regarding ecotourism because it brings popularity to nature protection, it brings incomes and influence nature protection. The principles of sustainable tourism also emphasise the necessity of protecting natural values (Stojanović, 2011) because it is the only way how this activity can serve nature protection.

Apart from the fact that it can be observed in the correlation with nature protection, the process of sediment remediation can be observed through techniques of managing certain area. In the last couple of year great attention of scientists and institutions of spatial planning and nature protection has been paid upon studying, planning and protecting landscapes. A landscape is a multidimensional phenomenon that encompasses all abiotic and biotic components of one territory as well as cultural characteristics if present on that territory. There are different dimensions in the process of researching landscape. In ecology that is an agglomerate of ecosystems and it is observed functionally. European Landscape Convention was signed in Florence in 2000 and it started being practically applied in 2004. Since then its practical importance has been observed in many European countries.

The importance of protecting landscapes in Vojvodina is described in Regional spatial strategy which emphasises the necessity of protecting the structures of one landscape and natural processes, all aimed at promoting and sustainable using of those areas (Regional spatial strategy of the Autonomous Province of Vojvodina, 2011). Few studies have been made so far concerning the fact that even sedimentation causes unfavourable consequences to the landscape and negative effects to its natural values, resources and as- 


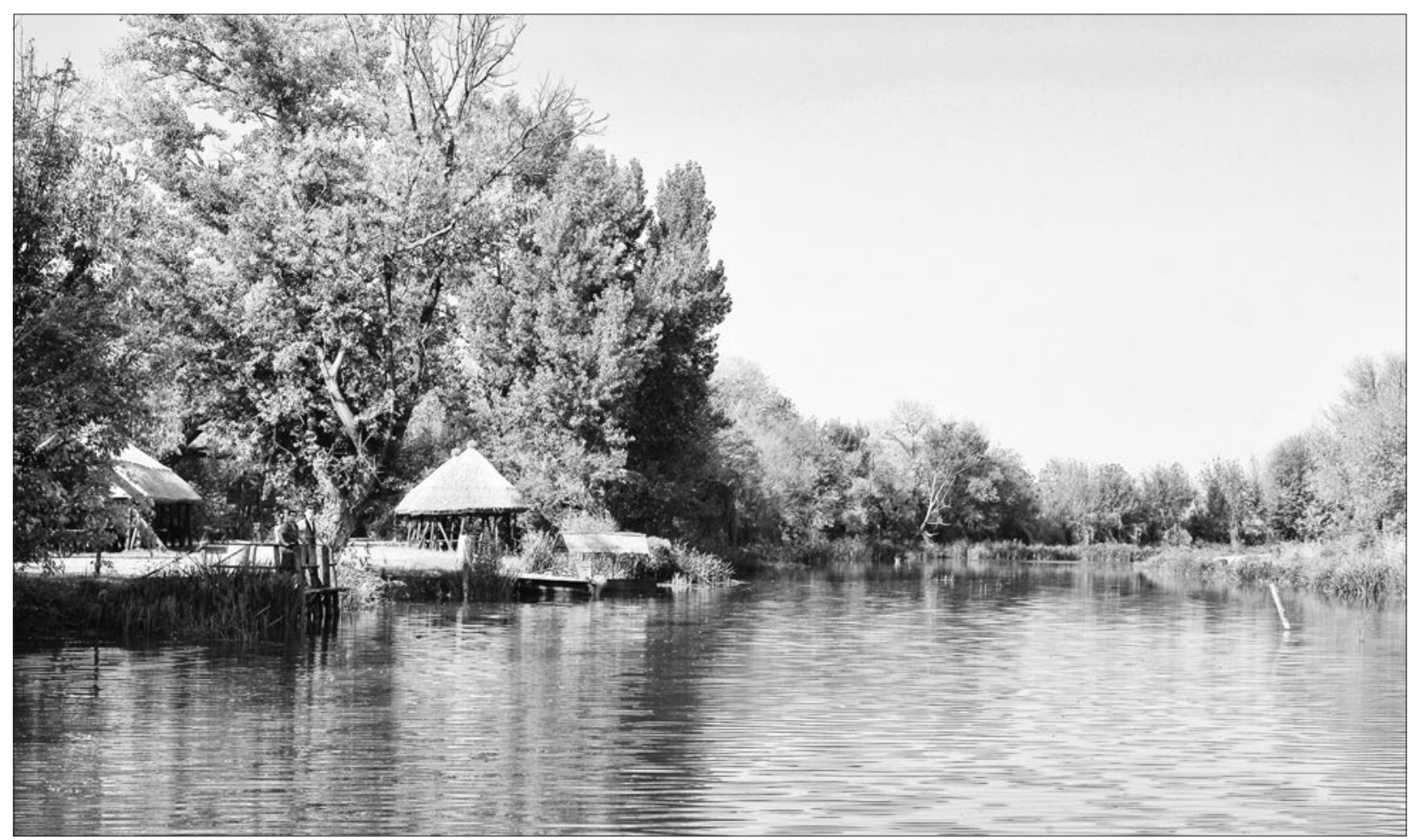

Figure 4. Northern part of Stari Begej course restored its original form and open and clean surface after the process of demudding which is of great importance for a certain number of functions in this protected area

pect of environmental protection. Such kind of process can be analysed in those parts of the reserve that through the process of demudding restored their original forms (Figure 4). Conception and vision of nature protection should be more intensely placed in the correlation with protected areas, factors that endanger them and with sediment remediation.

\section{Conclusion}

The landscape in the reserve Carska bara and around it has a long chronology of systematic changes which makes it possible to define the territory as a cultural area with well-preserved fragments of nature. The best preserved fragments of that nature are the objects of surface hydrography - marshes, lakes, and river arms that all function as isolated systems due to numerous alternations. Widely spread poor fen communities and phytocenosis of sedge-dominated communities serve as indicators of damaging changes. The tendency of their growth influences the reduction of free water surfaces and mudding. Consequences can even be seen in the problems of fresh water inflow and inability to intervene in order to connect hydrological frame of the reserve - the course of Stari Begej with surrounding marshes. Remediation through the process of demudding seems rather necessary because it contributes to the development of functions and reaching goals of nature protection in the reserve Carska bara. Apart from management of nature pro- tection, an emphasis must be paid upon education, tourism and stocking with fish.

The problem of mudding and the necessity of remediation through the process of demudding appear in some other protected areas in Vojvodina as well such as in "Gornje Podunavlje", "Koviljsko-petrovaradinski rit" or "Karađorđevo", which only makes this problem more contemporary in the field of nature protection.

\section{Acknowledgment}

The authors acknowledge the financial support of the Ministry of Education and Science of the Republic of Serbia (Project III 43005)

\section{References}

Budakov, Lj., Banjac, M., Branković, D., Butorac, B., Habijan-Mikeš, V., Ham, I., Kovačev, N., Kovačević, B., Kuzmanović, J., Bence, M., Pavkov, G., Stojšić, V., Vider-Milošević, V., 1993. Suggestion for the protection of nature reserve "Stari Begej-Carska bara" as a Special nature reserve. Institute for $\mathrm{Na}$ ture Conservation of Serbia, Novi Sad.

Dalmacija B., Tričković J., Agbaba J., Rončević S., Krčmar D., Pešić V., Tubić A., Dalmacija M., Božović Lj., Molnar J., Ivančev Tumbas I., Ugarčina S., Kragulj M., Barši A., Bečelić M., Watson M.A., Poguberović S., 2008. Monitoring of the chemical quality of surface waters and sediment in protected zones and 
ecological black spots in Vojvodina in 2008. Faculty of Sciences, Chair of Chemical Technology and Environmental Protection, Novi Sad, $143 \mathrm{pp}$.

Dalmacija B., Tričković J., Agbaba J., Ivančev Tumbas I., Kragulj M., Molnar J., Maletić S., Dalmacija M., Krčmar D., Rončević S., Pešić V., Watson M.A., Bečelić Tomin M., Rajić Lj., Ugarčina Perović S., Tubić A., Leovac A., Kerkez Đ., 2010. Research of the presence of priority substances in water and sediment in protected zones and selected locations of surface waters in the Autonomous Province of Vojvodina. Faculty of Sciences, Chair of Chemical Technology and Environmental Protection, Novi Sad, $108 \mathrm{pp}$.

Dawson, T.P., Berry, P.M., Kampa, E. 2003. Climate change impacts on freshwater wetland habitats. Journal for Nature Conservation 11, 25-30.

Erwin, K.L. 2009. Wetlands and global climate change: the role of wetland restoration in a changing world. Wetlands Ecology and Management 17, 71-84.

European Landscape Convention, Florence, 2000.

IPCC 2007. Climate Change 2007. The Physical Science Basis. Contribution of Working Group I to the Fourth Assessment Report of the Intergovernmental Panel on Climate Change [Solomon, S., D. Qin, M. Manning, Z. Chen, M. Marquis, K.B. Averyt, M. Tignor and H.L. Miller (eds.)]. Cambridge University Press, Cambridge, United Kingdom and New York, NY, USA: 996 pp.

Ham, I., 1975. Qualitative structure of the heron colony (Ardeidae) and influence of certain environmental factors on its creation in the area of Donji Begej in Vojvodina. Larus 26 - 28, Zagreb.

Medović, P., 2001. Prehistory in the area of Vojvodina. Prometej, Novi Sad, Vojnoizdavački zavod, Beograd, 135.

Marošan, A., Ćurčić, S., Bugarski, D., Tomić, P., Milojević, S., Kicošev, S., Pavlov, B., Đuričić, J., Kečkemeti, E., Kikinđanin, J., Borić, D., 1992. Ečka Fishpond. DD Ribarsko gazdinstvo Ečka, Lukino selo, 343 .

Mortsch, L. 1998. Assessing the impact of climate change on the Great Lakes shoreline wetlands. Climatic Change 40, 391-416.

Nježić, Z., Rosić, Z., 2008. Mud as an effluent from Ečka Fishpond waters, demudding as a measure of protection in the Special nature reserve „Stari Begej-Carska bara". Festival of quality, Third conference on the quality of life, Association for quality and standardisation of Serbia, Kragujevac.

Prato, T., Fagre, D., 2005. National Parks \& Protected Areas. Blackwell Publishing, Oxford, 446.

Suggestion of technical solution for removal of mud from part of the water course Stari Begej in Special nature reserve "Stari Begej - Carska bara", 2003.

Pil, N., Galamboš, L., Stojšić, V., Perić, R., Sekulić, N., Kovačev, N., Timotić, D., Kiš, A., Stanišić, J., Dobretić, V., Stojnić, N., Tucakov, M., Delić, J., Sabadoš, K., Kicošev, V., Cvijić, D., Bošnjak, T., Majkić, B., Čalakić, D., Banjac, M., 2010. Special nature reserve "Carska bara", suggestion for proclaiming the area as the protected area of the 1st level, study on the protection. Provincial Institute for Protection of Nature, Novi Sad, 177.

Regional spatial strategy of the Autonomous Province of Vojvodina, Urban and Spatial Planning Institute of Vojvodina, Novi Sad, 2011, 208.

RHMZ 1949-2010. Meteorological yearbook I. Republic Hydrometeorological Service of Serbia, Beograd. Spasov, P. 2003. Occurrence of drought in Serbia, its monitoring and forecasting possibilities. Water Resource Management 35, 30-36.

Stojanović, V., Pavić, D., Ristanović, B. 2009. The Implementation of the Principle of Sustainable Development in the Special Nature Reserve "Stari Begej-Carska bara”, Serbia. Geographica Pannonica 13, 1, 11-16.

Stojanović, V., 2011. Tourism and sustainable development. Department of Geography, Tourism and Hotel Management, Faculty of Sciences, Novi Sad, 260.

Regulation on the protection of the Special nature reserve „Stari Begej-Carska bara”, Official Gazette of the Republic of Serbia, No. 56, 1994.

Regulation on the protection of the Special nature reserve „Carska bara”, Official Gazette of the Republic of Serbia, No. 46, 2011.

Law on nature protection, Official Gazette of the Republic of Serbia, No. 36/2009.

Walther, G-R., Post, E., Convey, P., Menzel, A., Parmesank, C., Beebee, T.J.C., Fromentin, J-M., HoeghGuldberg, O., Bairlein, F. 2002. Ecological responses to recent climate change. Nature 416, 389-395. www.iucn.org 